\title{
Karakterisasi Morfologi Phytophthora sp. Asal Buah Kakao Desa Olo-oloho, Kabupaten Konawe, Sulawesi Tenggara
}

\author{
Muzuni $^{1, *}$, Haidin $^{2}$, Nur Arfa Yanti ${ }^{2}$ \\ ${ }^{1}$ Program Studi Bioteknologi FMIPA Universitas Halu Oleo Kendari \\ ${ }^{2}$ Program Studi Biologi FMIPA Universitas Halu Oleo Kendari \\ *e-mail Corresponding: muzuni_fmipa@uho.ac.id \\ Diterima: 24 April 2020 - Disetujui: 30 April 2020 - Dipublikasi: 05 Mei 2020 \\ ๑ 2020 Jurusan Biologi FMIPA Universitas Halu Oleo Kendari, Indonesia.
}

\begin{abstract}
This study aimed to determine the morphological characteristics of Phytophthora sp. isolated from cocoa fruits from Olo-oloho Village, Konawe Regency, Southeast Sulawesi. Isolation of Phytophthora sp. carried out by the point method using V4 (Vegetable Juice Agar) media incubated at $27^{\circ} \mathrm{C}$ for 24 hours. Morphological characterization of Phytophthora sp. included characterization of colony morphology and cell morphology. The results showed that the colony morphological characteristics were white colonies, cotton-like textures, the uneven edge of the colony, zoning and radial lines. The morphological characteristics of the cell had asexual spores in the form of sporangium and chlamydospores, hyphae are not aseptic, greenish-black zoospores, zoospores are round and double-flagged, and have sporangiophores.
\end{abstract}

Keywords: Phytophthora sp., colony morphology, cell morphology

\section{Abstrak}

Penelitian ini bertujuan untuk mengetahui karakteristik morfologi Phytophthora sp. yang di isolasi dari buah kakao asal Desa Olo-oloho Kabupaten Konawe Sulawesi Tenggara. Isolasi Phytophthora sp. dilakukan dengan metode titik menggunakan media V4 (Vegetable Juice Agar) dan diinkubasi pada suhu $27^{\circ} \mathrm{C}$ selama 24 jam. Karakterisasi morfologi isolat Phytophthora sp. meliputi karakterisasi morfologi koloni dan morfologi sel. Hasil penelitian menunjukkan karakteristik morfologi koloni isolat yaitu berwarna putih, tekstur menyerupai kapas, tepi koloni tidak rata, memiliki zonasi dan garis radial. Karakteristik morfologi selnya memiliki spora aseksual berupa sporangium dan klamidiospora, hifa tidak aseptat, zoospora berwarna hitam kehijauan, zoospora berbentuk bulat berflagel dua, serta memiliki sporangiofor.

Kata kunci: Phytophthora sp., morfologi koloni, morfologi sel.

\section{PENDAHULUAN}

Tanaman kakao (Theobroma cacao, L.) merupakan tanaman tropis, dikenal masyarakat Indonesia pertama kali tahun 1780 (Spilane, 1995), dan termasuk komoditas ekspor andalan penyumbang devisa bagi negara, penyediaan lapangan kerja, serta merupakan mata pencaharian masyarakat Indonesia (Sulistyowati et al., 2003), Selain itu kakao dibutuhkan sebagai bahan baku industri makanan dan minuman, industri farmasi, industri kosmetika (Wahyudi et al., 2008).

Tahun 2014, produksi kakao di Sulawesi Tenggara hanya sebanyak 125.079 ton, dan mengalami penurunan pada tahun 2015 dengan memproduksi kakao sebanyak 105.434 ton dengan luas lahan perkebunan kakao mencapai 29.880 ha. Penurunan produksi ini disebabkan 
karena menurunnya produksi kakao di sentral-sentral penghasil kakao, termasuk di Kabupaten Konawe. Kabupaten Konawe hanya memproduksi kakao sebanyak 7.877 ton pada tahun 2014, padahal potensinya dapat mencapai 14.514 ton. Hal ini disebabkan karena lahan perkebunan kakao yang mencapai 1.893 ha tidak produktif (Nasir, 2015).

Menurut Goenadi et al. (2005) agribisnis kakao Indonesia masih menghadapi berbagai masalah kompleks antara lain produktivitas kebun masih rendah akibat serangan hama seperti penggerek buah kakao (PBK), penyakit busuk buah maupun kerusakan fisik yang ditimbulkan akibat kesalahan saat pemanenan. Hal tersebut mengakibatkan buah kakao memiliki mutu rendah.

Penurunan produksi kakao di Kabupaten Konawe disebabkan karena adanya serangan jamur Phytophthora yang merupakan kelompok Oomycetes. Jenis Phytophthora yang menyerang buah kakao setiap daerah di Indonesia, telah diketahui identitasnya berdasarkan penelitian Umayah dan Purwantara (2006). Menurut Purwantara dan Prawirosoemardjo (2006), spesies Phytophthora yang menyebabkan penyakit pada kakao di daerah Provinsi Sulawesi Tenggara khususnya di Kabupaten Kolaka adalah Phytophthora palmivora. Namun, jenis Phytophthora yang menyerang tanaman kakao di Kabupaten Konawe belum diketahui secara pasti. Oleh karena itu, perlu adanya identifikasi lebih mendalam mengenai morfologinya.

Identifikasi Phytophthora secara morfologi dapat dilakukan berdasarkan bentuk dan ukuran sporangia menurut petunjuk identifikasi (Stamps et al., 1990). Sifat morfologi yang digunakan untuk identifikasi adalah tipe koloni, bentuk hifa, produksi dan diameter klamidospora, dan percabangan sporangiofor (Bush, et al., 2006).
Berdasarkan sifat morfologi di atas, maka perlu dikembangkan identifikasi Phytophthora berdasarkan karakter morfologi sel dan morfologi koloninya. Karakter morfologi sel yang dapat diamati pada isolat Phytophthora sp., terdiri atas bentuk koloni, warna koloni di atas permukaan, warna koloni di bawah permukaan, tekstur koloni, tepi koloni, zonasi, dan garis radial. Sedangkan karakter morfologi sel yang diamati pada isolat Phytophtora sp., terdiri atas spora aseksual berupa sporangium dan klamidiospora, tipe hifa, sporangiofor, zoospora, bentuk zoospora, warna zoospora. Berdasarkan karakter tersebut, maka jenis Phytophthora yang diidentifikasi dapat ditentukan.

\section{METODE PENELITIAN}

\section{Alat dan bahan}

Alat dan bahan yang digunakan dalam penelitian ini meliputi mikropipet, timbangan analitik, shaker, oven, erlenmeyer, gelas ukur, cawan petri, pipet ukur, jarum ose, media PDA dan media V4 dan buah kakao yang terserang jamur serta akuades dan alkohol $70 \%$.

\section{Prosedur Penelitian}

\section{Sumber Isolat}

Proses pengambilan sampel dilakukan di Kabupaten Konawe Sulawesi Tenggara, Desa Olo-Oloho, Kecamatan Uepai. Pengambilan sampel buah kakao yang terserang Phytophthora sp. dengan cara mengambil buah yang busuk secara acak kemudian Phytophthora sp. diisolasi dari buah di laboratorium.

\section{Media V4 (Vegetable Juice)}

Media yang digunakan untuk peremajaan isolat Phytophthora sp., adalah Media V4 (Vegetable Juice). Komposisi media V4 yaitu agar $20 \mathrm{~g}$, ekstrak V4 200 g (Daun seledri, Tomat, Bayam dan Wortel), $\mathrm{CaCO}_{3} 3 \mathrm{~g}$, dan akuades $800 \mathrm{~mL}$ (Banasuru, 2015), 
kemudian dipanaskan di Hot plate dan dihomogenkan dengan menggunakan magnetic stirrer dan disterilisasi dengan autoklaf. Media tersebut digunakan untuk pertumbuhan isolat pada media padat, sedangkan media yang tanpa penambahan agar digunakan sebagai media pertumbuhan isolat pada media cair.

\section{Karakterisasi Morfologi Koloni}

Isolasi Phytophthora sp. dilakukan dengan metode titik menggunakan media V4 (Vegetable Juice Agar) (Banasuru, 2015). Sampel kakao yang berjamur diambil dengan menggunakan ose pada bagian miseliumnya, lalu diinokulasi pada cawan petri yang berisi media V4 (Vegetable Juice Agar). Selanjutnya isolat diinkubasi pada suhu $27^{\circ} \mathrm{C}$ selama 5 hari dan dilakukan pengamatan setiap 24 jam, dan selanjutnya morfologi koloni diamati. Morfologi koloni yang diamati meliputi: bentuk koloni, warna koloni, diameter, tekstur, dan permukaan koloni.

\section{Karakterisasi Morfologi Sel}

Media V4 dipanaskan dengan menggunakan Hot plate hingga berwujud cair. Selanjutnya, isolat diinokulasi di kaca preparat steril dan isolat diteteskan dengan media V4 yang telah berwujud cair serta ditutup dengan menggunakan kaca penutup. Metode yang dilakukan yaitu menggunakan metode slide culture. Isolat diinkubasi pada suhu ruang selama 24 jam, kemudian dilakukan pengamatan. Isolat diinkubasi pada suhu sekitar $29^{\circ} \mathrm{C}$ selama 5 hari dan dilakukan pengamatan setiap 24 jam, dan selanjutnya dilakukan pengamatan morfologi sel yang meliputi: bentuk zoospora, klamidiospora, sporangium dan tipe hifa.

\section{HASIL DAN PEMBAHASAN}

\section{Karakteristik Morfologi Koloni Phytophthora sp.}

Karakter morfologi sel yang diamati pada isolat Phytophthora sp., terdiri atas bentuk koloni, warna koloni di atas permukaan, warna koloni di bawah permukaan, tekstur koloni, tepi koloni, zonasi, dan garis radial. Hasil pengamatan morfologi koloni isolat yang dilakukan dengan metode titik pada media V4 (Vegetable Juice Agar) ditunjukkan pada Tabel 1.

Tabel 1. Karakteristik morfologi koloni Phytophthora sp., setelah 5 hari inkubasi.

\begin{tabular}{|c|c|c|}
\hline No & Karakter Isolat & $\begin{array}{l}\text { Isolat } \\
\text { Phytophthora } \\
\text { sp. }\end{array}$ \\
\hline 1. & Bentuk koloni & Bulat \\
\hline 2. & $\begin{array}{l}\text { Warna koloni di atas } \\
\text { permukaan (surface) }\end{array}$ & Putih \\
\hline 3. & $\begin{array}{l}\text { Warna koloni di } \\
\text { bawah permukaan } \\
\text { (reverse) }\end{array}$ & Coklat \\
\hline $\begin{array}{l}4 . \\
5 . \\
6 . \\
7 . \\
8 .\end{array}$ & $\begin{array}{l}\text { Tekstur Koloni } \\
\text { Tepi Koloni } \\
\text { Zonasi } \\
\text { Garis Radial } \\
\text { Diameter (mm) }\end{array}$ & $\begin{array}{l}\text { Seperti Kapas } \\
\text { Tidak Rata } \\
\text { Ada } \\
\text { Ada } \\
90.73\end{array}$ \\
\hline
\end{tabular}

Berdasarkan Tabel 1 menunjukkan bahwa isolat kapang yang diisolasi dari buah kakao merupakan kelompok dari genus Phytophthora yang di tandai dengan bentuk koloni bulat, berwarna putih, tepi koloni tidak rata, adanya zonasi serta terdapat garis radial pada koloni kapang. Karakterisasi ini sesuai dengan hasil karakterisasi penelitian sebelumnya Banasuru et al. (2015) bahwa genus Phytophthora secara makroskopis koloninya berbentuk bulat, teksturnya seperti kapas, tepi koloni tidak rata, terdapat garis radial serta terdapat zonasi jika ditumbuhkan pada media V4. Selain itu, menurut Motulo dkk. (2007) bahwa karakteristik koloni $P$. palmivora pada umumnya berbentuk bulat dengan pinggiran yang tidak rata dan berwarna putih. Karakter morfologi koloni Phytophthora sp. juga ditunjukkan pada Gambar 1. 


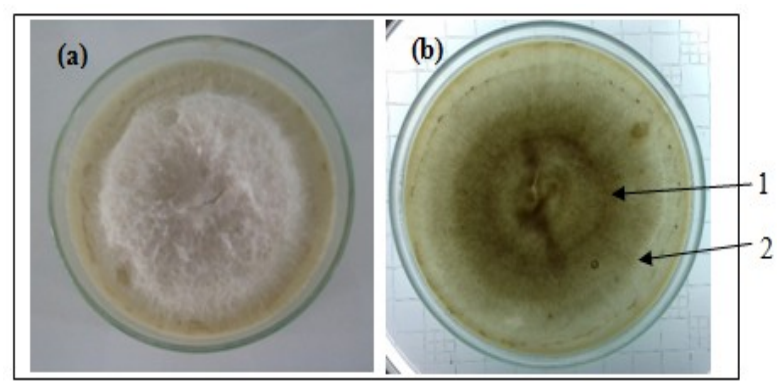

Gambar 1. Karakter koloni Phytophthora sp. a: warna koloni di atas permukaan (surface), b: warna koloni di bawah permukaan (reverse). 1 : Garis radial, 2: Zonasi.

Pertambahan diameter koloni kapang menunjukkan terjadinya petumbuhan yang semakin hari semakin membesar (Tabel. 2). Gandjar dan Sjamsuridzal (2006) mengatakan bahwa salah satu parameter pertumbuhan adalah pertambahan volume sel yang bersifat irreversibe tidak dapat kembali ke volume semula, yang disebabkan karena pembentukan hifa vegetatif. Berdasarkan penjelasan Gandjar, dkk. (2014) bahwa hifa vegetatif merupakan hifa yang menempel pada substrat media dan berperan dalam mengabsorbsi nutrisi, sehingga memperluas area penyebaran hifa tersebut.

Berdasarkan pengamatan diameter koloni pada Tabel 2 menunjukkan adanya pertumbuhan isolat Phytophthora sp., selama inkubasi yang ditumbuhkan pada media V4 dan PDA. Pertumbuhan nampak cepat pada media V4 dibandingkan pada media PDA. Beberapa penelitian menunjukkan bahwa Phytophthora umumnya tumbuh lambat pada media PDA yang membutuhkan waktu 5-12 hari inkubasi (Umaya dan Purwantara, 2006; Pratama dkk., 2017).
Tabel 2. Diameter koloni isolat Phytophthora sp. yang di tumbuhkan pada media V4 dan PDA

\begin{tabular}{|c|c|c|c|c|c|c|}
\hline \multirow[b]{2}{*}{ Media } & \multirow[b]{2}{*}{ Isolat } & \multicolumn{5}{|c|}{ Diameter (mm) } \\
\hline & & $\begin{array}{l}\text { Hari } \\
\text { ke-1 }\end{array}$ & $\begin{array}{l}\text { Hari } \\
\text { ke-2 }\end{array}$ & $\begin{array}{l}\text { Hari } \\
\text { ke-3 }\end{array}$ & $\begin{array}{l}\text { Hari } \\
\text { ke-4 }\end{array}$ & $\begin{array}{l}\text { Hari } \\
\text { ke } 5\end{array}$ \\
\hline V4 & Phytophthora & 18,7 & 34,5 & 69,1 & 81,3 & 90,73 \\
\hline PDA & & - & - & - & - & 10,4 \\
\hline
\end{tabular}

Pertumbuhan Phytophtora yang cepat pada media V4 dibandingkan media PDA, disebabkan karena pada media V4 mengandung nutrisi yang lebih lengkap yaitu karbohdrat dan vitamin-vitamin yang berasal dari sayuran yang merupakan bahan baku dari media V4, sedangkan pada media PDA kandungan hanya didominasi karbohidrat. Banasuru (2015) dalam penelitiannya menyatakan bahwa pertumbuhan koloni Phytophthora merupakan pertumbuhan fast growth atau kapang yang memiliki pertumbuhan cepat pada media V4 dibandingkan PDA, dengan membutuhkan komponen karbohidrat tinggi dan beberapa vitamin untuk pertumbuhannya. Lahmuddin (2013), dalam penelitiannya menyatakan bahwa Phytophthora umumnya tumbuh lambat pada media PDA dengan membutuhkan waktu 5-7 hari inkubasi.
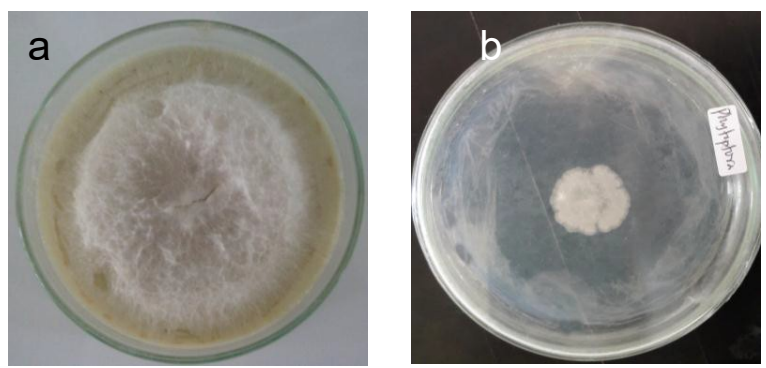

Gambar 2 : Morfologi koloni Phytophthora sp., yang di tumbuhkan pada media: a: V4, b: PDA, selama 5 hari inkubasi

Karakteristik Morfologi Sel Phytophthora sp.

Karakter morfologi sel yang diamati pada isolat Phytophtora sp., terdiri atas 
spora aseksual berupa sporangium dan klamidiospora, tipe hifa, sporangiofor, zoospora, bentuk zoospora, warna zoospora. Pengamatan morfologi sel dilakukan dengan metode slide culture untuk mempermudah pengamatan yang dilakukan di bawah mikroskop. Hasil pengamatan karakteristik morfologi sel isolat kapang dengan menggunakan mikroskop disajikan pada Tabel 3.

Tabel 3. Karakteristik morfologi sel isolat Phytophthora sp. pada media Vegetable Jus Agar (V4)

\begin{tabular}{|c|c|c|}
\hline No. & Karakter & $\begin{array}{l}\text { Morfologi Sel } \\
\text { Isolat } \\
\text { Phytophthora }\end{array}$ \\
\hline 1 & 2 & 3 \\
\hline 1. & Spora Aseksual & $\begin{array}{l}\text { Sporangium dan } \\
\text { Klamidiospora }\end{array}$ \\
\hline 2. & Tipe Hifa & Asepta \\
\hline 3. & Zoospora & Ada \\
\hline 4. & Bentuk Zoospora & $\begin{array}{l}\text { Bentuk Bulat } \\
\text { berflagel }\end{array}$ \\
\hline 5. & Warna Zoospora & Hitam Kehijauan \\
\hline 6. & Sporangiofor & Ada \\
\hline
\end{tabular}

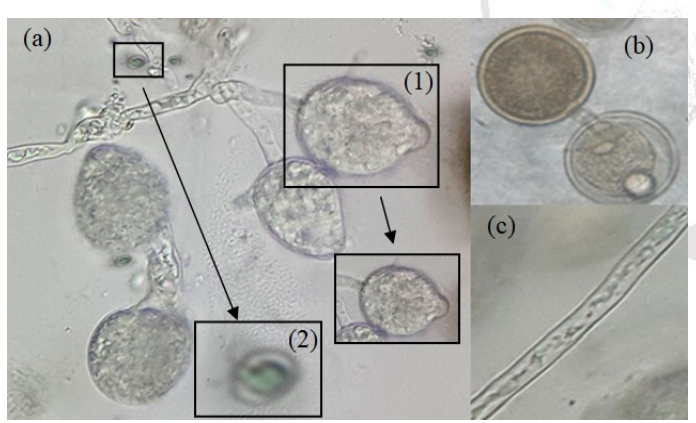

Gambar 3. Hasil Karakterisasi morfologi sel isolat Phytophthora sp. menggunakan pembesaran 400x. a: Morfologi sel Phytophthora, 1: Sporangium, 2: Zoospora; b: Klamidiospora, c: Hifa aseptat.

Pengamatan mikroskopis isolat kapang pada Tabel 3 menunjukkan bahwa Phytophthora sp. memiliki karakter morfologi sel berupa spora aseksual yaitu sporangium berbentuk lonjong dengan tonjolan di ujungnya. Dalam sporangium terdapat zoospora yang berflagel dua (Gambar 3a), klamidiospora berbentuk bulat berdinding tebal (Gambar 3b). Tipe hifa asepta atau tidak memiliki dinding sel (Gambar 3c) berdasarkan karakter tersebut, isolat kapang diindikasi merupakan genus Phytophthora. Hal ini didukung oleh hasil penelitian Stamps et al. (1990) yang menyatakan bahwa adanya genus Phytophthora memiliki ciri hifa asepta, spora aseksual berupa sporangium berbentuk papilate dengan ukuran (30-60 x 20-50 $\mu \mathrm{m})$. Selain itu, Masanto et al. (2019) menunjukkan bahwa ciri genus Phytophthora memiliki tipe hifa asepta, klamidospora berbentuk bulat, dan zoospora berflagel. Klamidiospora berwarna hitam sebagai fase dormansi akibat kondisi yang tidak baik (Waterhouse, 1974; Erwin \& Ribeiro, 1996; Drenth \& Sendall, 2004).

\section{PENUTUP}

\section{Simpulan}

Karakteristik morfologi koloni isolat Phytophtora sp. dari buah kakao asal Desa Olo-oloho Kabupaten Konawe Sulawesi Tenggara yaitu berwarna putih, tekstur menyerupai kapas, tepi koloni tidak rata, memiliki zonasi dan garis radial. Karakteristik morfologi selnya memiliki spora aseksual berupa sporangium dan klamidiospora, hifa tidak aseptat, zoospora berwarna hitam kehijauan, zoospora berbentuk bulat berflagel dua, serta memiliki sporangiofor.

\section{UCAPAN TERIMA KASIH}

Kami berterima kasih kepada Kementerian Riset, Teknologi dan Pendidikan Tinggi, Republik Indonesia atas biaya yang telah diberikan dalam bentuk Hibah Penelitian Dasar Unggulan Perguruan Tinggi Tahun 2019 an. Dr. Muzuni, S.Si., M.Si. dengan judul isolasi dan pengklonan gen kitinase tanaman kakao sebagai salah satu upaya pengendalian penyakit yang disebabkan oleh Phytophthora palmivora dan Oncobasidium theobromae pada tanaman kakao. 


\section{DAFTAR PUSTAKA}

Banasuru, G. 2015. Isolasi dan Karakterisai Morfologi Phytophthora Palmivora Pada Buah Kakao pada Perkebunan Kakao di Konawe Selatan, Sulawesi Tenggara, Skripsi, Fakultas Teknologi dan Ilmu Pangan, Jurusan Agroteknologi, UHO, Kendari.

Bush, E.A., Stromberg, E.L., Hong, C., Richardson, P. A., and Kong, P. 2006. Illustration of key morphological characteristics of Phytophthora species identified in Virginia nursery irrigation water. Online. Plant Health Progress doi:10.1094/PHP-2006-0621-01RS.

Drenth, A., and Sendall, B. 2001. Pratical Guide to Detection and Identification of Phytophthora. CRC for Tropical Plant Protection, Brisbane, Australia.

Erwin, D.C., and Ribeiro, O.K. 1996. Phytophthora Diseases Worlwide. American Phytopathological Society. St. Paul, Minnesota. p. 408-421.

Gandjar, I.R., dan Sjamsuridzal, W. 2006. Mikologi Dasar dan Terapan : Edisi Pertama, Yayasan Pustaka Obor, Jakarta.

Gandjar, I.R., Sjamsuridzal, W. dan Oetari, A. 2014. Mikologi Dasar dan Terapan : Edisi revisi, Yayasan Pustaka Obor, Jakarta.

Goenadi, H.D., Baon, B., Herman, dan Purwoto, A. 2005. Prospek dan Arah Pengembangan Agribisnis Kakao di Indonesia. Badan Litbang Pertanian. Hal 27.

Masanto, Wibowo, A., Subandiyah S., and Kageyama, K. 2019. Morphometric variation of Phytophthora palmivora causing black pod rot disease on cocoa (Theobroma cacao L.) in Indonesia. Plant Pathol. J., 18: 111.

Motulo, H.F.J., Sinaga, M.S., Mandang S., dan Tjahjoleksono, A. 2007. Karakter morfologi dan molekuler isolat Phytophthora palmivora asal kelapa dan kakao. Jur. Pen. Tan. Industri, 13:111-118.

Nasir, G. 2015, Statistik Perkebunanan Indonesia Komoditas Kakao, 20142016, Direktorat Perkebuan Jakarta.

Pratama, P.I., Sulistyowati, L. dan Djauhari, S. 2017. Eksplorasi jamur endofit pada tanaman kakao (Theobroma cacao L.) serta potensi antagonismenya terhadap Phytophthora palmivora Butler. penyebab penyakit busuk buah secara in vitro. Jurnal HPT, 5(2): 61-66.

Purwantara, A. dan Prawirosoemardjo, 2006, Fluktuasi Intensitas Serangan Terhadap Phytophthora palmivora Butl. pada Buah Kakao di Daerah Beriklim Basah. Menara Perkebunan 58: 44-50.

Spilane, J.J. 1995. Komoditi Kakao Peranannya dalam Perekonomian Indonesia. Yogyakarta, Kanisius. 11.

Stamps, D.J., Waterhouse, G.M., Newhook F.J., dan Hall, G.S.1990. Revised Tabular Key To The Species Of Phytophthora. Common. Agric. Bur. Int. Mycol. Inst. Mycol. Pap. 162. 28 pp.

Sulistyowati, E., Yohanes, D.J., Sri, S., Sukadar, W., Loso, W., dan Nova, P. 2003. Risalah Simposium Nasional Penelitian PHT Perkebunan Rakyat. Analisis Status Penelitian dan Pengembangan PHT pada Tanaman Kakao. Bogor.

Umayah, A dan Purwantara, A. 2006. Identifikasi isolat Phytophthora asal kakao. Menara Perkebunan, 74(2): 76-85.

Wahyudi, T., Pujiyanto, dan Panggabean, T.R. 2008. Panduan Lengkap Kakao: Manajemen Agribisnis dari Hulu Hingga Hilir, Penebar Swadaya, Jakarta.

Wibowo, O.A, Sudarma, I.M. dan Puspawati, N.M. 2017. Uji Daya Hambat Jamur Eksofit terhadap Phytophthora palmivora (Butler) Butler Penyebab Penyakit Busuk Buah Kakao secara In Vitro. J. Agroekoteknologi Tropika, 6(3): 279-289. 